\title{
Path To Financial Inclusion: The Success Of Self-Help Groups-Bank Linkage Program In India
}

Sivakumar Venkataramany, Ashland University, USA Balbir B. Bhasin, Sacred Heart University, USA

\begin{abstract}
Financial inclusion has been a major theme in both industrialized and developing economies in the era of financial globalization. When microcredit institutions have received limited success in many countries, microfinance is being used in India for the purpose of accomplishing universal financial inclusion. This paper recognizes the overwhelming efforts of the Government of India and focuses on the success of the linkage between commercial banks and self-help groups (SHGs). The SHGs comprising predominantly women groups help in the social cause of alleviation of poverty, , increase of sustainability, reduction of vulnerability, improvement of capacity building and help the weaker sections build assets. Increased education, better standard of living, reduced child mortality and child labor, emancipation cum empowerment of women, and communal harmony are value adding benefits to the country.
\end{abstract}

Keywords: Financial Inclusion, Financial Exclusion, Self-Help Groups (SHGs), Micro lending, Microfinance

\section{INTRODUCTION}

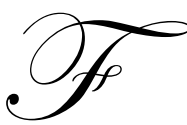

inancial sector reform in India since independence is essentially focused on the theme of universal financial inclusion but the objective still remains a work in process. Various steps have yielded target oriented results such as branch expansion for commercial banks thanks to nationalization, creation of Regional Rural Banks to assist the farming sector, and state sponsored programs in financing the priority sector. The country has had consistent attempts to offer innovative solutions such as, the Integrated Rural Development Program (IRDP), to the problems of the poor. These efforts became predominantly felt in the post-nationalization era of major banks. The country's overwhelming steps to promote small, medium and micro enterprises in their entrepreneurial progress and skill development are considered a dire need (Venkataramany and Fox, 2009).

India has received foreign direct investment of about $\$ 100$ billion from 1991 to 2008 but still about 240 million people are estimated to be living below poverty line. The country is well-served by numerous types of financial institutions - 84 commercial banks, 133 regional rural banks, 55 corporations, 13,014 non-banking finance co-operative societies (NBFCs), and 111,777 co-operative institutions. The formation of the National Bank for Agriculture and Rural Development (NABARD) was the highlight of numerous efforts of the Government of India.

\section{LITERATURE REVIEW}

\section{An International Perspective of Financial Exclusion and Financial Inclusion}

Financial globalization has caused banks to focus on their key credit markets and global portfolio of assets thereby relying on local dynamics for aspects of financial inclusion or financial exclusion (Dymski, 2005). Access to basic banking services for the transmission of money services is an accurate way to assess financial exclusion. Financial exclusion occurs when some members or households are denied access to all financial services. The reasons for the exclusion may stem from past history and culture of the society. It eventually leads to societal 
problems such as widespread poverty, concerns of health, lack of education and illiteracy, unemployment, and poor productivity. Financial exclusion thus is a systemic problem hampering sustainable development. Governmental efforts to thwart it are usually undermined by disintegrated regulatory practices (Vaas, 2007). Those without access to financial services have no other alternative but turning to informal and illegal market. They submit themselves to exploitation and predatory lending practices. The process of financial liberalization and economic integration in Mexico has paved way for foreign financial institutions to acquire six major local banks but low and medium income households' access to credit markets still remains limited (Biles, 2005). Financial exclusion can be found in both developed and developing economies.

Industrialized economies are not exception to cases of financial exclusion where the goal of financial inclusion involves resolution of conflict between social goal and profitability. The Saver Plus program of Australia would have been successful in encouraging savings behavior if it had included involvement of community groups, financial education and also co-contribution arrangements (Russell, Brooks, Nair and Fredline, 2006). Privatization of the postal system in Japan that has been a traditional savings vehicle has led to possible occurrence of financial exclusion (Kaneko and Metoki, 2008). Policy response in Europe for the promotion of basic financial inclusion has been ad hoc and country specific policy-making by the EC is not as effective as a national solution as seen in the US-style affirmative action (Carbo, Gardener and Molyneux, 2007).

The case of the UK has been addressed by numerous scholars whose studies have focused on financial inclusion, financial exclusion, and the Treasury's efforts to overcome the challenges. The country has realized that $f$ financial exclusion may be overcome and financial literacy may spread only through credit unions as they have a social purpose (Evans and Broome, 2005). Co-operative credit unions in the UK have served the cause of addressing poverty and promotion of financial inclusion. The support of the government especially the treasury's Financial Inclusion Fund has made an impact within financially excluded communities (Jones 2008). In the last two decades, community credit unions being small had marginal impact within financially excluded communities. The Financial Inclusion Task Fund has brought a significant transformation in the sector. The credit unions have grown to marketoriented and commercial social enterprises. Their capacity to tackle financial exclusion from a local reach to national appeal has flourished (Jones, 2006). The growth of the Community Development Loan Fund (CDLF) as alternative financial institutions in the UK was mainly to overcome financial exclusion to disadvantaged households and promote financial inclusion (Buttle and Bryson, 2005). In the past two decades, increased costs of adopting advanced technology and the need for cost reduction have made the mainstream of financial services infrastructure to be only in urban and metropolitan centers. Their imminent withdrawal from lower income suburbs has given an opportunity to costly sub-prime lenders thrive. Area-based solutions have been considered a viable, affordable, and social-welfare oriented alternative to assist disadvantaged communities. Unless these units embed themselves in the communities they serve, their limitations would undermine their very existence as evidenced by Financial Inclusion Newcastle (FIN) in the North East of England (Fuller, 2008). Financial inclusion must include the three essential dimensions of banking, consumer credit and insurance and the importance of the concept has become more felt in cashless economies (Collard, 2007).

In Spain, groups at risk of social and financial exclusion are supported by individual loans through the country's microenterprise initiatives (Garrido and Calderón, 2006). Financial exclusion in Spain also explains the concept of financial deepening and bank dependence (Valverde, Carbó; and Francisco, 2004). Financial deepening involves the development of traditional and non-traditional financial services. Bank dependence makes reliance on banks by households and firms heavy. Most discussions on financial exclusion point towards the retail banking services but it must include access to home mortgages as evidenced in the case study of Milan (Aalbers, 2007). Financial exclusion in Canada is more concentrated among low-income households. Naturally, such households are not mainly interested in new banking technologies but only in gaining access to financial services (Buckland and Xiao-Yuan, 2008). .A society with financial exclusion also suffers from unemployment, reduced production levels and lack of productivity resulting in a high debt to output ratio as evidenced in the emerging economies (Hatchondo, Martines, and Sapriza, 2007). Lessons learned from Sub-Saharan emerging economies suggest that several socioeconomic factors must be included in the formulation of monetary policy and programs besides good governance (Chibba, 2008). 


\section{FINANCIAL EXCLUSION AND EFFORTS FOR FINANCIAL INCLUSION IN THE INDIAN CONTEXT}

Poor and non-poor people in many developing countries experience severe financial exclusion thereby creating obstacles for growth and reducing income inequality. Finance creates value and ensures efficient resource allocation (Beck and Demirgüç-Kunt, 2008). It is worth examining whether access to credit is a right. Access to financial services may help the poor in several ways but it may also lead to excessive indebtedness too (Hudon, 2009), a view endorsed by the planning commission of India. Sparsely populated hilly areas with poor infrastructure, difficulty of access, lack of awareness among consumers, social exclusion, low income and illiteracy are some of the important reasons for financial exclusion in India (Throat, 2007). The Indian perspective of financial inclusion emphasizes access to financial services in three specific dimensions of credit, wealth creation and contingency management. Beyond credit, the provision of a wide range of financial services, including saving accounts, insurance, and remittance facilities are needed. Credit in itself is considered good if it is self-liquidating and is used for production of units that could be sold for a price. It also increases employment for the borrower and the entire household. The credit must address credit needs of the disadvantaged households for entrepreneurial livelihood, emergency loans, residential mortgages, and consumer loans. For the goal of poverty alleviation to be fulfilled, financial inclusion must ensure that poor people also may work towards wealth creation through savings and investment plans. Contingency planning must include retirement planning for pension benefits, insurable contingencies for health care, crop insurance and asset protection, and also some buffer savings.

The Government of India constituted a "Committee on Financial Inclusion" and the Committee submitted its final report to the finance ministry in January 2008. The committee has defined Financial Inclusion as "the process of ensuring access to financial services and timely and adequate credit where needed by vulnerable groups such as weaker sections and low income groups at an affordable cost." It has recommended setting up of two funds namely, Financial Inclusion Fund (FIF) and Financial Inclusion Technology Fund (FITF). The two funds have been established with NABARD which is the coordinating agency for all initiatives of financial inclusion. There are several forms of financial institutions offering microcredit. Domestic commercial banks in the public and private sector at the national level and Regional Rural Banks (RRB), co-operative banks, registered \& unregistered nonbanking finance corporations (NBFC) and other trusts \& societies at the regional level provide superfluous services to ensure total financial inclusion. While $95 \%$ of the salaried class has bank accounts, only $14 \%$ of agricultural labor force has access to similar facilities. 79\% of the people in the low income group receive credit assistance from the informal market such as, money lenders. Thus, the financial system in India has at times failed to reach out to the poor and weak sections of the society mostly due to the undesirable intervention by the state as indicated by blanket moratoriums, interest subsidies, and also non-commercial interferences. The limited disbursals made by the system to the poor as rural credit for development are also seemingly not collectible thereby undermining the sustainability and potential of rural finance (Rao, Mahajan, Leeladhar, Vasimalai, Reddy, Mohan, Sriram and Vikalpa, 2005).

According to the Planning Commission of India, there are about 16,400 non-governmental organizations (NGOs) voluntarily engaged in finding sustainable development for the poor. An earlier study undertaken in 2002 by PRIA, an International Center for learning and promotion of participation and democratic governance in association with the Institute for Policy Studies, Johns Hopkins University had estimated that nearly 1.2 million nonprofit organizations (NPOs) were operating in India in 2000. These NPOs operated with about $\$ 4$ billion mostly funded by domestic households. They remained largely invisible but with widespread impact because they were private, self-governing, voluntary, and non-profit distributing (Tandon and Srivastava, 2002). Many multinational corporations are also assisting government, aid agencies and NGOs in reducing poverty through trade. Unilever, Proctor \& Gamble and CEMEX are all recent examples in integrating social innovation strategies in its business operations (Stefanovic, 2007). Unilever in partnership with NGOs has created Shakti, a rural network that employs 31,000 women and sells products to rural customers in more than 100,000 villages. India has numerous national and regional programs such as, Self Employed Women's Association (SEWA), Swarnajayanti Gram Swarozgar Yojana (SGSY) and Society for Helping Awakening of Rural Poor through Education (SHARE). Our focus will be on one important dimension namely, the Self-Help Group (SHG) wherein the NGOs play a vital role voluntarily. 


\section{SELF-HELP GROUPS}

While microcredit refers to credit assistance of a low magnitude, microfinance offers a broad perspective for universal financial inclusion by adding thrift, savings, insurance and other financial services to credit. The SelfHelp Groups (SHGs) represent a non-institutional channel of microfinance. An SHG is a registered or unregistered group of micro entrepreneurs having similarities in their social and economic background, voluntarily forming a cohesive group. The members agree to save small amounts regularly thereby pooling their savings into a common fund and their emergency needs are supported by the common fund on a mutual help basis. The group members use collective wisdom and peer pressure to ensure proper end-use of credit and timely repayment thereof, a method recognized as an effective substitute for collaterals. An individual from a weak and vulnerable group gains strength by being a part of a cohesive group. The objectives of the SHG program are to alleviate poverty, increase sustainability, reduce vulnerability, improve capacity building and help the weaker sections build assets. Increased education, better standard of living, reduced child mortality and child labor, emancipation cum empowerment of women, and communal cum religious harmony are value adding benefits to the country. Through the membership in a homogeneous team, women area able to engage in active production, embed their skills in a network for potential synergistic opportunities, become aware of numerous government and non-government programs, and also overcome social limitations.

Financing through SHGs reduces transaction costs for lenders and borrowers at the same time. Lenders have to handle only a single SHG account which makes it a commercially viable transaction. They do not have to handle a large number of small-sized individual accounts. Borrowers save expenses on travel and time in completing applications and supporting documents. They do not have to suffer loss of wages by missing workdays in order to get a small loan. Minimizing transactions costs of micro-payments is only one part of the task. The transaction involves a systematic investment plan (SIP) of four dollars per month by aggregation for the whole group of ten members which implies a saving of forty cents by each individual. Ten years ago, banks permitted SHGs to open bank accounts and it is time that mutual funds recognized SHGs as legitimate participants.

\section{SHG-BANK LINKAGE PROGRAM}

The national bank for Agriculture and Rural Development (NABARD) launched a pilot project on savings and credit management in 1986 in conjunction with Mysore Resettlement and Development Agency (MYRADA). An enhanced effort came into place permanently in 1991 with the SHG-bank linkage program whereby the country's central bank advised commercial banks to consider credit assistance to SHGs to be included in the priority sector. There is some semblance of the Grameen bank Model in the SHGs but there are several differences in terms of number of individuals in a group, affinity, freedom, amount of credit and interest rates (Chandirakala, 2008). Two models of microfinance are practiced in India. The Self-Help Group (SHG)-Bank linkage model is the dominant channel where commercial banks lend directly to SHGs formed explicitly for this purpose. This serves as a meaningful link between commercial banks and the SHGs. The second model is the Microfinance Institution (MFI) model where MFIs borrow funds from banks for onward lending to microfinance clients, many of whom form joint liability groups for this purpose. As of March 2007, more than 2.9 million SHGs were linked to banks covering a total flow of credit of about five billion dollars as shown in Table 1. Until 2003, the majority of the SHGs were located in the four states in South India but the concept is being received with success in the northern part of the country in the past five years.

More than ninety percent of SHGs happen to be groups of women as shown in Table 2 and thus the system paves way for emancipation of women. Women entrepreneurs evolve and their production leads to the desired economic growth. There is ample literature available on women entrepreneurship. Johnson offers a feminine perspective and stresses on gender bias when it comes to financial exclusion (Johnson, 1999). Huge international financial institutions have successfully adapted viable business models in India as the country's landscape offers and demands. They are engaged in promoting financial literacy, skill development, and business knowledge among the poor, particularly rural women. These institutional efforts lead to the fulfillment of several environmental and social initiatives such as water conservation, sustainability and livelihood creation (Marar, Iyer and Brahme, 2009). The level of awareness of services, utilization and satisfaction provided by supporting agencies among women entrepreneurs tends to be low according to a study in select states of Northern India (Kumar, 2008). Numerous 
agencies are engaged in training programs furthering skill development, motivation and managerial input understanding the successful business models but some training centers are not as successful as those at the central and state levels (Nagesh and Narasimha, 2008).

\begin{tabular}{|c|cc|cc|}
\hline \multicolumn{4}{|c|}{ Table 1 Growth Pattern of SHG-Bank Linkage Program } \\
\hline \multirow{2}{*}{$\begin{array}{c}\text { Year ending } \\
\text { March 31 }\end{array}$} & $\begin{array}{c}\text { Total SHGs Financed by } \\
\text { Banks ('000) }\end{array}$ & \multicolumn{2}{c|}{$\begin{array}{c}\text { Bank Loans } \\
\text { (Millions) }\end{array}$} \\
\cline { 2 - 5 } & $\begin{array}{c}\text { During the } \\
\text { year }\end{array}$ & $\begin{array}{c}\text { Cumulative } \\
\text { total }\end{array}$ & $\begin{array}{c}\text { During the } \\
\text { year }\end{array}$ & $\begin{array}{c}\text { Cumulative } \\
\text { total }\end{array}$ \\
\hline $1992-99$ & 33 & 33 & $\$ 13.26$ & $\$ 13.26$ \\
2000 & 82 & 115 & $\$ 31.63$ & $\$ 44.88$ \\
2001 & 149 & 264 & $\$ 66.98$ & $\$ 111.86$ \\
2002 & 198 & 462 & $\$ 126.74$ & $\$ 238.60$ \\
2003 & 256 & 718 & $\$ 237.67$ & $\$ 476.28$ \\
2004 & 362 & 1,080 & $\$ 431.63$ & $\$ 907.91$ \\
2005 & 539 & 1,619 & $\$ 696.28$ & $\$ 1,604.19$ \\
2006 & 620 & 2,239 & $\$ 1,046.28$ & $\$ 2,650.47$ \\
2007 & 686 & 2,925 & $\$ 1,544.88$ & $\$ 4,195.35$ \\
\hline Source: The Reserve Bank of India, Annual Report 2008 (Adapted) \\
\hline \multicolumn{5}{|c}{} \\
\hline
\end{tabular}

\begin{tabular}{|c|c|c|c|c|c|c|}
\hline \multirow[b]{2}{*}{ Institution } & \multicolumn{3}{|c|}{ Total SHGs } & \multicolumn{3}{|c|}{ Exclusively for Women } \\
\hline & $\begin{array}{c}\text { Number of } \\
\text { SHGs }\end{array}$ & Lo & Disbursed & $\begin{array}{c}\text { Number of } \\
\text { SHGs }\end{array}$ & & Disbursed \\
\hline Public Sector Banks & 537,228 & $\$$ & $8,091,000$ & 466,318 & $\$$ & $6,915,674$ \\
\hline Private Sector Banks & 34,408 & $\$$ & $1,022,814$ & 32,802 & $\$$ & $1,001,721$ \\
\hline Total & 571,636 & $\$$ & $9,113,814$ & 499,120 & $\$$ & 7,917,395 \\
\hline
\end{tabular}

\begin{tabular}{|c|c|c|c|c|c|c|}
\hline \multicolumn{7}{|c|}{ Table 3 Bank Loans Outstanding against SHGs, March 31, 2007} \\
\hline Institution & $\begin{array}{c}\text { Number of } \\
\text { SHGs }\end{array}$ & Share $(\%)$ & & $\begin{array}{l}\text { Amount } \\
\text { (million) }\end{array}$ & Share $(\%)$ & $\begin{array}{c}\text { Outstanding } \\
\text { Loan per SHG }\end{array}$ \\
\hline Public Sector Banks & $1,810,353$ & $62.5 \%$ & $\$$ & $2,350.00$ & $66.5 \%$ & 1,057 \\
\hline Private Sector Banks & 82,663 & $2.9 \%$ & $\$$ & 152.86 & $4.3 \%$ & 1,505 \\
\hline Regional Rural Banks & 729,255 & $25.2 \%$ & $\$$ & 800.57 & $22.7 \%$ & 893 \\
\hline Co-operative Banks & 272,234 & $9.4 \%$ & $\$$ & 229.71 & $6.5 \%$ & 685 \\
\hline Total & 2,894,505 & $100.0 \%$ & $\$$ & 3,533.14 & $100.0 \%$ & 1,221 \\
\hline
\end{tabular}


Public sector banks and regional rural banks offer financial services to nearly 80 percent and 90 percent of credit facilities to the SHGs as shown in Table 3. The average loan per group is about $\$ 1,200$ which implies that an individual member of an SHG has an outstanding loan of $\$ 60$.

The recovery rate for the credit facilities has been satisfactory. About 37 percent of banks reported recovery of above 95 percent under the program. Thirty six percent of banks reported recovery in the range of 80 to 94 percent while 20 percent banks had recovery in the range of 50 to 79 percent. Only 7 percent of banks had a recovery rate of less than 50 percent as indicated in Table 4.

\begin{tabular}{|l|c|c|c|c|}
\hline \multicolumn{5}{|c|}{ Table 4 Recovery Indicators for Bank Loans given to SHGs } \\
\hline \multicolumn{1}{|c|}{ Institution } & $\begin{array}{c}\text { 95 per cent } \\
\text { and above }\end{array}$ & $\begin{array}{c}\text { 80 to 94 per } \\
\text { cent }\end{array}$ & $\begin{array}{c}\text { 50 to 79 per } \\
\text { cent }\end{array}$ & $\begin{array}{c}\text { less than 50 } \\
\text { per cent }\end{array}$ \\
\hline Commercial Banks & $30.60 \%$ & $41.70 \%$ & $27.80 \%$ & $0.00 \%$ \\
Regional Rural Banks & $27.40 \%$ & $47.90 \%$ & $17.80 \%$ & $6.80 \%$ \\
Co-operative Banks & $42.00 \%$ & $30.40 \%$ & $19.30 \%$ & $8.30 \%$ \\
Total & $36.90 \%$ & $36.20 \%$ & $20.00 \%$ & $6.90 \%$ \\
\hline Source: The Reserve Bank of India, Trend and Progress of Banking in India, 2007-08 \\
\hline
\end{tabular}

\begin{tabular}{|l|c|c|c|r|}
\hline \multicolumn{5}{|c|}{ Table 5 Savings by and Loans Outstanding to SHGs } \\
(as of March 31, 2007) \\
\hline \multirow{4}{*}{ Institution } & \multicolumn{2}{c|}{ Savings } & \multicolumn{2}{c|}{ Loans } \\
\cline { 2 - 5 } & $\begin{array}{c}\text { Number of } \\
\text { Accounts } \\
(\mathbf{0 0 0})\end{array}$ & $\begin{array}{c}\text { Amount } \\
\text { (million) }\end{array}$ & $\begin{array}{c}\text { Accounts } \\
\text { ('000) }\end{array}$ & $\begin{array}{r}\text { Amount } \\
\text { (million) }\end{array}$ \\
\hline Commercial Banks & $2,293.77$ & $\$ 440.10$ & $1,893.01$ & $\$ 2,037.30$ \\
Regional Rural Banks & $1,183.07$ & $\$ 269.37$ & 729.26 & $\$ 651.57$ \\
Co-operative Banks & 683.75 & $\$ 107.44$ & 272.23 & $\$ 187.06$ \\
Total & $\mathbf{4 , 1 6 0 . 5 9}$ & $\mathbf{\$ 8 1 6 . 9 1}$ & $\mathbf{2 , 8 9 4 . 5 0}$ & $\mathbf{\$ 2 , 8 7 5 . 9 3}$ \\
\hline Source: NABARD Annual Report $2007-08$ & & \\
\hline
\end{tabular}

\begin{tabular}{|l|c|c|c|c|}
\hline \multicolumn{5}{|c|}{ Table 6 Savings of Exclusive Women SHGs } \\
(as of March 31, 2007) \\
\hline \multicolumn{1}{|c|}{ Institution } & $\begin{array}{c}\text { Number of } \\
\text { Accounts } \\
\text { ('000) }\end{array}$ & Share & $\begin{array}{c}\text { Amount of } \\
\text { Savings }\end{array}$ & Share \\
\hline Commercial Banks & $1,794.73$ & $54.9 \%$ & $\$ 383.95$ & $54.6 \%$ \\
Regional Rural Banks & 974.81 & $29.8 \%$ & $\$ 242.56$ & $34.5 \%$ \\
Co-operative Banks & 501.71 & $15.3 \%$ & $\$ 76.98$ & $10.9 \%$ \\
Total & $\mathbf{3 , 2 7 1 . 2 5}$ & $100.0 \%$ & $\mathbf{\$ 7 0 3 . 4 9}$ & $100.0 \%$ \\
\hline Source: The Reserve Bank of India, Trend and Progress of Banking in India, 2007-08 \\
\hline
\end{tabular}


The concept of microfinance is very much realized in that as more than four million savings accounts have been opened for SHGs by the commercial banks but only about 2.9 million of them have obtained credits from the banks as shown in Table 5.

Table 6 shows evidence of commercial banks and regional rural banks controlling about 85 percent of savings accounts opened exclusively by women SHGs.

\section{CONCLUSION}

The Planning Commission of India is considering six major steps to be undertaken for universal financial inclusion. First, India needs an organizational structure that facilitates inclusion by promoting small banks despite their lack of viability due to high fixed costs. They must be able to provide both asset and liability products to small clients. Second is the focus on risk mitigation whereby vulnerable sections of society may afford low-cost insurance protection for life, healthcare, agricultural output and any other contingency through formation of micro-insurance firms. Third, norms pertaining to priority sector lending targets and the, use of government subsidies must be revisited and institutional changes need to be introduced including a deregulated interest rate environment. The debate whether interest rate ceilings benefit the poor produces varied results. Countries with interest rate ceilings have poor market penetration as seen in Tunisia and Colombia but those without ceilings have better penetration as evidenced in Bolivia and Morocco (Helms and Reille 2004). Fourthly, the use of technology must become prevalent to reduce the effective cost of delivery of financial products. The Boston Consulting Group report estimates the cost of funds to be 9 percent, provision for bad debts is 10 percent and the combined costs of consumer acquisition, transaction and operation cost is 13 percent for the weaker sections thus making financial services to be unprofitable. Overall improvement of infrastructure for financial inclusion and the propagation of financial literacy are the last two items for implementation.

Though we have witnessed the decline of government-funded institutions in the international sphere, cooperatives have to combat financial exclusion. International and public sector organizations still can enhance the ability of co-operatives so that their members may have access to a variety of financial services (Rogaly, 1998). Research on banking mainly examines only the banking needs of core customers but, the views of people experiencing financial exclusion remain always unknown (Panigyrakis, Theodoridis,and Veloutsou, 2002). As of now, the SHGs are able to serve nearly 60 million people and the task of bringing the remaining 180 million people still living below poverty line is a daunting task. Seeking relief from problems and providing welfare is the primary goal of the SHGs and the success thereof would lead to a strong community development ensuring eradication of social evils in the environment. Sustainable systems development and the integration of all sections would be the ultimate benefits for India.

\section{AUTHOR INFORMATION}

Dr. Venkataramany serves as an Associate Professor of Management in the Dauch College of Business \& Economics at Ashland University, Ashland, Ohio where he teaches global management and global finance. Besides teaching commitments abroad, he also serves as an examiner for doctoral theses. He received his MBA, MS and Ph.D. from the University of Miami, Coral Gables, Florida. His research interests are risk management in global banks, emerging financial markets and FDI in developing economies.

Balbir B. Bhasin serves as an Associate Professor of International Business at the John F. Welch College of Business, Sacred Heart University, Fairfield, Connecticut and Luxembourg. He holds a Master of International Management degree from Thunderbird School of Global Management, Glendale, Arizona and a Ph.D. in International Business from the University of South Australia, Adelaide, Australia. He was the president of a private investment bank in New York, and CEO of an international business information company in the Far East. His research interests are in cross-cultural studies and FDI in Asian markets. He advises companies on opportunities in Emerging Asia. 


\section{REFERENCES}

1. Aalbers, Manuel. B., "Geographies of Housing Finance: The Mortgage Market in Milan, Italy", Growth \& Change, Jun2007, Vol. 38 Issue 2, pp. 174-199

2. Beck, Thorsten; Demirgüç-Kunt, Asli, “Access to Finance: An Unfinished Agenda", World Bank Economic Review, 2008, Vol. 22 Issue 3, pp. 383-396

3. Biles, James J., "Globalization of Banking and Local Access to Financial Resources: A Case Study from Southeastern Mexico", Industrial Geographer, Spring 2005, Vol. 2 Issue 2, pp. 159-173

4. Buckland, Jerry; Xiao-Yuan Dong. "Banking on the Margin in Canada", Economic Development Quarterly, Aug2008, Vol. 22 Issue 3, pp. 252-263

5. Buttle, Martin; Bryson, John R., "Enabling inclusion through Alternative Discursive Formations: The Regional Development of Community Development Loan Funds in the United Kingdom", Service Industries Journal, Mar2005, Vol. 25 Issue 2, pp. 273-288

6. Carbo, Santiago, Gardener, Edward P. M.; Molyneux, Philip. "Financial Exclusion in Europe", Public Money \& Management, Feb2007, Vol. 27 Issue 1, p21-27

7. Chandirakala, P., "A study of Empowerment of Women through bank Credit under Self-Help Groups in Tiruvallur District of Tamilnadu, Ph.D. Thesis, University of Madras, India, November 2008

8. Chibba, Michael. "Monetary Policy for Small Emerging Market Economies: The Way Forward", Macroeconomics \& Finance in Emerging Market Economies, Oct2008, Vol. 1 Issue 2, pp. 299-306

9. Collard, Sharon. "Toward Financial Inclusion in the UK: Progress and Challenges", Public Money \& Management, Feb2007, Vol. 27 Issue 1, pp. 13-20

10. Dymski, Gary A., "Financial Globalization, Social Exclusion and Financial Crisis", International Review of Applied Economics, Oct2005, Vol. 19 Issue 4, pp. 439-457

11. Evans, Rachel; Broome, Nerys, "Financial Nous and the Cycle of Deprivation: What Role Can Credit Unions Play?', Business Law Review, Oct2005, Vol. 26 Issue 10, pp. 231-235

12. Fuller, Duncan and Mellor, Mary, "Banking for the Poor: Addressing the Needs of Financially Excluded Communities in Newcastle upon Tyne":, Urban Studies (Sage), 2008, Vol. 45 Issue 7, pp. 1505-1524

13. Garrido, Silvia Rico; Calderón, Maricruz Lacalle, "Microcredits Granted in Spain: a Unique Model", "Finance \& the Common Good", Bien Commun, Autumn2006 Issue 25, pp. 94-100

14. Hatchondo, Juan Carlos; Martines, Leonardo; Sapriza, Horacio, "Quantitative Models of Sovereign Default and the Threat of Financial Exclusion”, Economic Quarterly, Summer2007, Vol. 93 Issue 3, pp. 251-286

15. Helms, Brigit and Reille, Xavier, "Interest Rate Ceilings and Microfinance: The Story So Far", Consultative Group to Assist the Poor (CGAP), Occasional Paper 9, September 2004

16. Hudon, Marek, "Should Access to Credit be a Right?" Hudon, Marek. Journal of Business Ethics, Jan2009, Vol. 84 Issue 1, pp. 17-28

17. Johnson, Susan, “New Economy, New Equality?”, New Economy, Jun99, Vol. 6 Issue 2, pp. 110-114

18. Jones, Paul A., "From Tackling Poverty to Achieving Financial Inclusion-The Changing Role of British Credit Unions in Low Income Communities", Journal of Socio-Economics, Dec2008, Vol. 37 No. 6, pp. 2141-2154

19. Jones, Paul A., "Giving Credit Where It's Due: Promoting Financial Inclusion through Quality Credit Unions". Local Economy, Feb2006, Vol. 21 Issue 1, pp. 36-48

20. Kaneko, Yuko; Metoki, Masahiko, "Postal Savings for National Development-The Experience of Japan and Future Perspective in a Globalized World", Public Organization Review, Sep2008, Vol. 8 Issue 3, pp. 233-252

21. Kumar, Anil, "Awareness of Supporting Agencies Among Women Entrepreneurs in Small Businesses", ICFAI Journal of Entrepreneurship Development, Dec 2008, Vol. 5, Issue 4, pp. 6-17

22. Marar, Pramod; Iyer, Balaji S.; Brahme, Unmesh., "HSBC Brings a Business Model of Banking to the Doorsteps of the Poor". Global Business \& Organizational Excellence, Jan/Feb 2009, Vol. 28 Issue 2, pp. $15-26$

23. Nagesh, P.; Murthy, M. S. Narasimha, "The Effectiveness of Women Entrepreneurship Training Program: A Case Study", ICFAI Journal of Entrepreneurship Development, Sep2008, Vol. 5 Issue 3, pp. 23-40

24. Panigyrakis, George G.; Theodoridis, Prokopis K.; and Veloutsou, Cleopatra A., "All Customers are Not Treated Equally: Financial Exclusion in Isolated Greek Islands", Journal of Financial Services Marketing, Aug2002, Vol. 7 Issue 1, pp. 54-66 
25. Report of the Committee on Financial Sector Reforms, “A Hundred Small Steps”, Planning Commission, Government of India, Sage Publications, 2009, pp.

26. Rogaly, Ben, "Combating Financial Exclusion through Co-operatives: Is There a Role for External Assistance?”, Journal of International Development, Sep/Oct1998, Vol. 10 Issue 6, pp. 823-836

27. Russell, Roslyn, Brooks, Robert; Nair, Aruna; and Fredline, Liz, "The Initial Impacts of a Matched Savings Program: The Saver Plus Program”, Economic Papers, Mar2006, Vol. 25 Issue 1, pp. 32-40

28. Sinha, Jammejaya., and Subramanium, Arvind, "The Next Billion Customers: A Road Map for Expanding Financial Inclusion in India”, Boston Consulting Group Report, November 2007

29. Sisodia, N. S.; Rao, M. B. N.; Mahajan, Vijay; Leedladhar, V.; Vasimalai, M. P.; Reddy, Rama; Mohan, Brij; Srinivasan, R.; Sriram, M. S.. Vikalpa, "Rural Finance in Contemporary Times: Interface with Microfinance", "The Journal for Decision Makers", Apr-Jun 2005, Vol. 30 Issue 2, pp. 81-112

30. Stefanovic, Marija, "New Business-NGO Partnerships Help the World's Poorest", International Trade Forum, Issue 2, 2007, pp. 6-9

31. Tandon, Rajesh and S.S. Srivastava, "PRIA Non-Governmental Organizations", Planning Commission of India, December 2002

32. Thraot, Usha, "Financial Exclusion - The Indian Experience", The Reserve Bank of India Monthly Bulletin, July 2007, pp. 1165-1172

33. Vaas, Peter, "Solving Financial Exclusion Needs Joined-Up Government", Public Money \& Management, Feb2007, Vol. 27 Issue 1, pp. 3-4

34. Valverde, Santiago Carbó; Fernández, Francisco Rodríguez, "The Finance-Growth Nexus: A Regional Perspective”, European Urban \& Regional Studies, Oct2004, Vol. 11 Issue 4, pp. 339-354

35. Venkataramany, Sivakumar and Fox, Daniel, "Globalization of Entrepreneurship: Overwhelming Institutional Response in Favor of SMEs in India", International Business and Economics Research Journal, Vol8, No.3, pp. 131-139 
NOTES 